\title{
Characterization of sperm motility in sea bass: the effect of heavy metals and physicochemical variables on sperm motility
}

\author{
F.J. Abascal ${ }^{1, *}$, J. Cosson ${ }^{2}$ and C. Fauvel ${ }^{3}$
}

${ }^{1}$ Instituto Español de Oceanografía, Unidad de Cádiz, Puerto Pesquero, Muelle de Levante s/n, Apdo. 2609, 11006 Cádiz, Spain.

2 UMR 7009, CNRS Marine Station, 06230 Villefranche sur mer, France.

${ }^{3}$ Institut Français de recherche pour l'exploitation de la mer, Station Expérimentale d'Aquaculture, Chemin de Maguelone, F-34250 Palavas les Flots, France.

*: Corresponding author: Abascal F. J., Tel.: +34 956 016015; fax: +34 956 016019, email address : francisco.abascal@uca.es

\begin{abstract}
:
Computer assisted sperm analysis (CASA) was used to characterize the motility of sea bass Dicentrarchus labrax spermatozoa and to study the effect of several physicochemical variables and heavy metals on sperm swimming performance. Duration of sperm motility in sea bass was very short (<50 s). During the first $20 \mathrm{~s}$ all the motility variables measured remained approximately constant, the velocity and linearity of the movement being maximum during this period, while both variables decreased sharply later. While slight variations in $\mathrm{pH}$ did not significantly modify sperm swimming performance, changes in osmolality affected all the measured motility variables. Two of the heavy metals tested, $\mathrm{Cu}^{2+}$ and $\mathrm{Pb}^{2+}$, did not affect sperm motility when the activating media contained up to 100 ppm of the metal salts. In contrast, $\mathrm{Hg}^{2+}$ modified the morphology of post-swimming spermatozoa at 0.4-1 ppm (sperm dilution rate 1:39) and completely arrested sperm motility at concentrations as low as $0.1 \mathrm{ppm}$ (sperm dilution rate 1:2500). Assuming a covalent binding to sperm cells, this revealed a finite number of $\mathrm{c}$. 10 million $\mathrm{Hg}^{2+}$ binding sites per spermatozoon. Complementary results using demembranated spermatozoa suggested that the main target of $\mathrm{HgCl}_{2}$ would be located in the plasma membrane and that $\mathrm{HgCl}_{2}$ would inhibit water channels, hence preventing sperm motility.
\end{abstract}

Keywords: CASA • Dicentrarchus labrax • heavy metals • sperm 


\section{Introduction}

Due to the fact that the majority of pollutants end up in coastal waters, fish inhabiting these areas are often exposed to chronic concentrations of different toxic compounds. Apart from the possible effects via the endocrine system leading to disruptions of genital activity (Kime \& Nash, 1999; Arukwe, 2001), external environment can affect reproduction by alteration of the released gametes, since the majority of teleost species show external fertilisation. Ova are not ideal pollution bioindicators since, at the present knowledge, their quality can only be measured through time-consuming fertilization experiments. Moreover, the results of these experiments are subjected to the variability of both sperm and ova, which viability can vary due to known but uncontrolled factors like overripening (Brooks et al., 1997 ).

Sperm fertility has been shown to be related to sperm motility in several fish species, including seabass Dicentrarchus labrax (L.) (Fauvel et al., 1999). The use of sperm motility parameters as indicators of toxicity and, consequently, the use of fish sperm as biomonitors have been addressed by previous studies (Kime et al., 1996; Kime \& Nash, 1999; Kime et al., 2001). Fish sperm motility has been reported to be clearly influenced by external variables such as temperature (Vladic \& Jaervi, 1997; Alavi \& Cosson, 2005), pH (Ingermann et al, 2002; Alavi \& Cosson 2005), osmolality (Morisawa \& Suzuki, 1980; Ohta \& Shinriki, 1998; Litvak \& Trippel, 1998; Haddy \& Pankhurst, 2000; Cosson, 2004; Alavi \& Cosson, in press), and various xenobiotic substances (Khan \& Weis, 1987a, b, c; Kime et al., 1996; Rurangwa et al., 1998, 2002; Ciereszko \& Dabrowski, 2000; Van Look, 2001; Wagner et al., 2002; Van Look \& Kime, 2003).

In the last years, computer assisted sperm analysis (CASA) systems, which were initially developed to examine male fertility in clinical andrology laboratories, have been employed to assess the sperm motility of different teleost species (Christ et al., 1996; Kime et al., 1996; Ravinder et al., 1997; Rurangwa et al., 2002; Van Look \& Kime, 2003). This method provides a fast and objective tool for assessing the quality of the sperm and the possible effects of different environmental conditions.

In the present study, the effect of temperature, salinity and $\mathrm{pH}$ on sperm swimming performance has been tested. Determination of optimal values of these variables can serve for optimising current in vitro fertilization protocols.

As a model for evaluating the effect of contaminants on sperm motility by means of a CASA system, the effect of three heavy metals (mercury, lead and copper), which are major pollutants in the industrial world, has been examined.

\section{Material and methods}

\section{Gamete collection}

This study was carried out on 16 hatchery-reared males weighing between 240 and $700 \mathrm{~g}$ during the natural spawning period of the species (January - March). Spermiating males were placed in 2 tanks at a stocking density of $10 \mathrm{~kg} \cdot \mathrm{m}^{-3}$. The flowing rate was $15 \%$ of the tank volume per hour. Seabass were daily fed ad libitum with pellets and fresh traw-fish was provided once a week. Fish were subjected to natural temperature and photoperiod during the preceding year. In order to prevent modifications due to seasonal variations, the males were maintained in winter conditions, i.e. at $13^{\circ} \mathrm{C}$ and a photoperiod of $8 \mathrm{~h}$ light/ $16 \mathrm{~h}$ dark during the experiment.

For sampling, the fish were not anesthetized. They remained quiet out of the water by using a cloth to cover their eyes while stripping. After rinsing with distilled water and careful drying of the genital area, sperm was collected in 2-ml syringes by a gentle pressure on the abdomen and placed in $1.5 \mathrm{ml}$ eppendorf tubes. Faeces and urine (checked by colour and viscosity variations) were discarded. 


\section{Sperm preparation and activation}

In order to ensure a synchronous activation of all the spermatozoa at the same time, a two-step dilution procedure was used (Billard \& Cosson, 1992). The two media used (non-activating and activating medium, NAM and AM, respectively) were prepared according to previous formulation (Dreanno, 1998). Sperm was first transferred to NAM (pH $=8.2$, osmolality $150 \mathrm{mOsm} / \mathrm{kg}$ ) at a 1:24 dilution rate and kept in a waterbath at $13^{\circ} \mathrm{C}$ during the experiment. Spermatozoa were activated by adding $5 \mu$ of this sperm suspension to an eppendorf tube containing $495 \mu$ l of AM $(\mathrm{pH}=8.2$, osmolality $1165 \mathrm{mOsm} / \mathrm{kg})$, thus leading to a final dilution of 1:2500. After a rapid homogenization, $3 \mu \mathrm{l}$ of the activated sperm were placed on a Thoma cell with a coverslip on the microscope stage so that observation and recording could start within the first $5 \mathrm{sec}$ after sperm activation. Room temperature was set around $13^{\circ} \mathrm{C}\left( \pm 2^{\circ} \mathrm{C}\right)$.

\section{Effect of physicochemical conditions on sperm motility}

Seabass semen osmolality is around $400 \mathrm{mOsm} / \mathrm{kg}$ (Villani \& Catena, 1991) and natural activation of the spermatozoa usually takes place in seawater at around $13^{\circ} \mathrm{C}, \mathrm{pH}=8.2$ and $1100 \mathrm{mOsm} / \mathrm{kg}$. In order to study the effect of these three factors on sperm swimming performance, osmolality of the AM was modified by dilution with distilled water or addition of $\mathrm{NaCl}$, to 580,870 and $1320 \mathrm{mOsm} / \mathrm{kg}, \mathrm{pH}$ was adjusted to 7.0, 7.5, and 8.5, and sperm was activated in control $\mathrm{AM}$ at $15^{\circ} \mathrm{C}$ and $20^{\circ} \mathrm{C}$.

\section{Effect of heavy metals on sperm motility}

The metal stock solutions were made up from analytical grade mercuric chloride $\left(\mathrm{HgCl}_{2}\right)$, copper chloride $\left(\mathrm{CuCl}_{2} \cdot 2 \mathrm{H}_{2} \mathrm{O}\right)$ and lead chloride $\left(\mathrm{PbCl}_{2}\right)$. Experimental concentrations were chosen on the basis of preliminary trials. In a first series of assays, sperm was exposed to AM containing $0.01,0.1,1,10$ and $100 \mathrm{ppm}$ of the three metal salts tested. As explained below, an interaction between BSA and the mercuric salt was observed. Activation in AM without BSA gave similar results for the copper and lead salts but an apparent increased sensitivity to $\mathrm{Hg}^{2+}$ was observed. However, spermatozoa movement could not be easily tracked due to intense sticking to both slide and coverslip.

As the effect caused by $\mathrm{Hg}^{2+}$ was observed to be irreversible, a new experiment was designed. Sperm diluted in NAM without added BSA (dilution rate 1:200) was exposed to several concentrations of $\mathrm{HgCl}_{2}$ (ranging from 0 to $1 \mathrm{ppm}$ ) during $\sim 5 \mathrm{~min}$ and then activated in $\mathrm{AM}$ containing $10 \mathrm{mM}$ BSA (final dilution rate 1:2500). This treatment prevented spermatozoa from sticking to coverslip and slide.

\section{Effect of $\mathrm{HgCl}_{2}$ on the morphology of native and demembranated spermatozoa}

In order to check the toxicity mechanism of $\mathrm{Hg}^{2+}$, sperm was first diluted in NAM (dilution 1:3) and then activated in control and Hg-enriched AM (dilution 1:10). Reactivation of flagellar movement was adapted from the procedure of extraction and reactivation described in the rainbow trout Oncorhynchus mykiss (Walbaum) by Cosson et al. (1995). For membrane permeabilization, $20 \mu \mathrm{l}$ of the sperm diluted in AM was added to $180 \mu \mathrm{l}$ of demembranation medium (DM) containing K-Acetate at $75 \mathrm{mM}$, DTT $1 \mathrm{mM}, \mathrm{CaCl}_{2} 0.5 \mathrm{mM}$, EDTA $0.5 \mathrm{mM}$, Tris $\mathrm{HCl} 20 \mathrm{mM}$, Triton X100 $0.04 \%(\mathrm{w} / \mathrm{v})$ adjusted to $\mathrm{pH}$ 8.2. After a $30 \mathrm{~s}$ incubation, $2 \mu \mathrm{l}$ of this suspension was mixed with $18 \mu \mathrm{l}$ of reactivation medium (RM) composed of K-Acetate at 150 $\mathrm{mM}$, DTT $1 \mathrm{mM}, \mathrm{MgSO}_{4} 1 \mathrm{mM}$, ATP $1 \mathrm{mM}$ (vanadate free from Boerhinger), BSA $1 \mathrm{mg} / \mathrm{ml}$, Tris $\mathrm{HCl} 20 \mathrm{mM}, \mathrm{pH}$ 8.2. $\mathrm{HgCl}_{2}$ was also added to the RM, in order to compare the sensitivity of native and demembranated sperm to the heavy metal.

Images of native and permeabilized spermatozoa in movement were obtained using the method described by Cosson et al. (1997). Briefly, spermatozoa were observed with an Olympus BH2 microscope using oil immersion objective (Olympus 40X D-Apo UV-oil 1.30 with diaphragm) combined with a dark field condenser (Olympus D F DWC 1.4-1.2). Records, obtained using stroboscopic illumination, were performed with a Panasonic WV-F15E S-VHS video-camera (frame rate: $50 \mathrm{~Hz}$ ), connected to a Panasonic AG $7330 \mathrm{~S}-\mathrm{VHS}$ video-recorder 
synchronized to the stroboscopic illumination with an optic fibre "video-sync" module \#9630 (Chadwick-Helmuth).

\section{Computer-assisted sperm analysis}

Sperm movement was recorded from the initiation time of activation until complete cessation of movement using a CCD camera attached to a light microscope with a phase contrast objective lens (20 x 1.25 magnification). Assessment of sperm motility was made using a Hobson sperm tracker (Hobson Tracking Systems Ltd., Sheffield, UK), with the following settings: search radius $=8.63 \mu \mathrm{m}$; predict $=$ off; video $=$ pal; aspect $=1.49$; refresh time $=1 \mathrm{~s}$; thresholds $=+20 /$ 100; filter weightings $1=1,2=4,3=2,4=1$; image capture rate $=25$ frames $\cdot \mathrm{s}^{-1}$.

For the characterization of sperm movement, spermatozoa were tracked each $5 \mathrm{~s}$ (minimum track time $=0.4 \mathrm{~s}$; immotile process $=$ off). The minimum interval for the Hobson sperm tracker to estimate the percentage of motile cells is $12 \mathrm{~s}$. Thus, spermatozoa were also tracked during the interval $5-17 \mathrm{~s}$ post-activation (minimum track time $=0.8 \mathrm{~s}$; immotile process $=$ shape).

The parameters assessed were curvilinear velocity (VCL), straight line velocity (VSL), average path velocity (VAP), percentage of motility (\%Mot), linearity (LIN), mean angular displacement (MAD), straightness (STR), lateral head displacement (ALH) and beat-cross frequency (BCF). For further details, see Kime et al. (1996).

\section{Statistical treatment}

The results obtained in each treatment were compared by single-factor analysis of variance. In the case of heterocedasticity (checked by the Cochran test), the non-parametric Kruskal-Wallis test was used (Zar, 1996). Multiple comparisons were performed using the Tukey's HSD, or the non-parametric Nemenyi, tests. The values of LIN and STR were arcsine-transformed prior to the statistical analysis (Zar, 1996).

Least-squares regression analyses were performed between mercury lethal concentration (LC100, concentration of the mercuric salt at which $100 \%$ of spermatozoa become immotile) and dilution factor or absorbance at $260 \mathrm{~nm}$, which is linearly proportional to sperm concentration (Fauvel et al., 1999). A $P$-value $\leq 0.05$ was considered statistically significant for all tests.

\section{Results}

\section{Characterization of seabass sperm motility}

Duration of motility in seabass was found to be short, all the spermatozoa being immotile at $50 \mathrm{~s}$ after activation. At each time point, the sperm population appears homogeneous, i.e. the behaviour of spermatozoa is very constant between individuals. The evolution of several motility parameters with time is shown in figure 1 . All the parameters remain approximately constant during the first 20-25 s. Then, VSL, VAP and VCL, which showed initial maximum values around $100 \mu \mathrm{m} / \mathrm{s}, 120 \mu \mathrm{m} / \mathrm{s}$ and $140 \mu \mathrm{m} / \mathrm{s}$, respectively, decrease progressively. At the end of the motility period, VSL and VAP show their minima, at around $20 \mu \mathrm{m} / \mathrm{s}$ and $40 \mu \mathrm{m} / \mathrm{s}$. The decrease in VCL is not so pronounced, getting to a velocity of $60 \mu \mathrm{m} / \mathrm{s}$. Concommitant to this lowering of the velocities, the movement becomes less linear, with LIN and STR, which at the first 25 seconds post-activation were around $65 \%$ and $80 \%$, respectively, falling to $20 \%$ and $50 \%$. The MAD shows an opposite trend, increasing from initial values around $30^{\circ}$ to $70^{\circ}$ at the end of the motility period. A slightly lower mean value of velocity is observed at the first $5 \mathrm{~s}$ time point, probably due to a slight drift generated right after placing the sample on the Thoma cell, what makes the system account certain inactive spermatozoa, thus lowering the average velocity. 


\section{Effect of physicochemical conditions on sperm motility}

In the case of $\mathrm{pH}$, significant differences were only found in VSL. However, multiple range tests did not reveal any difference. In general, spermatozoa activated in AM at intermediate $\mathrm{pH}$ values (7.5 and 8.2) showed higher velocities (VCL, VSL and VAP) and straighter movements (LIN and STR), while MAD was lower than those observed with sperm subjected to the extreme $\mathrm{pH}$ values assayed (7.0 and 8.5).

Osmolality, however, modified sperm swimming performance more effectively, especially during the first 15-20 s after activation. Table I shows the average values of different variables measured from 5 to $17 \mathrm{~s}$ post-activation. Roughly, sperm velocity reaches its maximum at an osmolality of $870 \mathrm{mOsm} / \mathrm{kg}$, while MAD and BCF display their minimum. Lin and STR increase slightly with osmolality, though there is no statistically significant difference but for the lowest osmolality, for which LIN and STR show their minima.

No difference was found when motility was assessed in AM at different temperatures.

\section{Effect of heavy metals on sperm motility}

When the sperm was activated in BSA-enriched $\mathrm{AM}$ containing $\mathrm{CuCl}_{2}, \mathrm{PbCl}_{2}$ or $\mathrm{HgCl}_{2}$ at concentrations of $0.01,0.1,1,10$ and $100 \mathrm{ppm}$, no significant difference in any of the variables studied was found, except for the case of $\mathrm{HgCl}_{2}$ at $100 \mathrm{ppm}$, which completely inhibited sperm motility (figure 2). A higher sensitivity of sperm to $\mathrm{HgCl}_{2}$ was found when activating in $\mathrm{AM}$ without BSA. However, spermatozoa could not be tracked because of the intense sticking. In these conditions (at a dilution rate of 1:2500), sperm motility was affected at concentrations of around $0.1 \mathrm{ppm}$ of $\mathrm{HgCl}_{2}$. No effect was observed in the case of the other metals tested.

Incubation in NAM without protein at the same dilution rates showed similar sensitivity to $\mathrm{Hg}^{2+}$, thus pointing to a covalent, irreversible binding of the compound. Then, a new experiment was designed: sperm diluted in NAM without added BSA (dilution 1/200) was exposed to different concentrations of $\mathrm{HgCl}_{2}$ during $\sim 5 \mathrm{~min}$ and then activated in $\mathrm{AM}$ with added proteins (so that spermatozoa did not stick to the Thoma slide or coverslip). The average values of VSL and ALH vs. metal concentration are plotted in figure 3. VCL and VAP showed the same trend as VSL. Subsequently, LIN and STR did not show any variation with metal concentration.

A significant and strong correlation was found between dilution factor and LC100, as can be seen in figure 4a. A significant, moderate relationship was also found between LC100 (at a sperm to NAM ratio of $1 / 50$ ) and absorbance of the same sperm diluted in distilled water (dilution rate $1 / 500$ ) at $260 \mathrm{~nm}$ (figure $4 \mathrm{~b}$ ).

\section{Effect of $\mathrm{HgCl}_{2}$ on the morphology of native and demembranated spermatozoa}

Spermatozoa subjected to low $\mathrm{Hg}^{2+}$ concentration showed high motility. However, the morphology of the cells was affected by the heavy metal at a concentration as low as $0.4 \mathrm{ppm}$ (dilution 1/30). Whereas control sperm flagella showed a slight and homogenous curvature at the end of its movement period (figure $5 \mathrm{a}$ ), a clear-cut break at various locations in the proximal part of the flagellum was observed in $\mathrm{Hg}$ treated sperm (figures $5 \mathrm{~b}$ and $5 \mathrm{c}$ ). This was followed (after 1-2 min incubation) by a shrinking of the whole flagellum, leading to the appearance of blebs, and then to partial disruption.

Up to $90 \%$ of demembranated spermatozoa were reactivated in the control conditions, with regular wave shape and propulsive motility when ATP was included at $1 \mathrm{mM}$ in the reactivation medium (RM). When $\mathrm{HgCl}_{2}$ was added to the RM, inhibition of reactivation was observed only for concentrations higher than $20 \mu \mathrm{M}$ (around $60 \mathrm{ppm}$ ). Because of the competitive effect of BSA towards $\mathrm{HgCl}_{2}$ observed with native spermatozoa, similar experiments were conducted without BSA in the RM: although a small proportion of permeabilized sperm cells were partly sticking to the glass surfaces, inhibitory effects of $\mathrm{HgCl}_{2}$ were observed at concentrations above $5 \mu \mathrm{M}$ (around $15 \mathrm{ppm}$ ). These are far higher values than those observed in native spermatozoa, which were completely inhibited at $\mathrm{HgCl}_{2}$ concentrations of $0.1 \mathrm{ppm}$. These spermatozoa showed regular movement of their axonemes after permeabilization and reactivation in control conditions. 


\section{Discussion}

The aim of this study was to set up a CASA system for the case of seabass spermatozoa and the evaluation, using this system, of the effect of several physicochemical parameters and pollutants on sperm quality. The Hobson Sperm Tracker provides a good estimation of several variables, allowing an objective measurement of sperm swimming performance, which is in turn directly related to sperm quality and fertilization capability (Lahnsteiner et al., 1998; Dreanno et al., 1999a; Lahnsteiner, 2000; Rurangwa et al., 2001). Once the settings are configured, it is possible to make numerous, fast and reproducible assays. This avoids the use of subjective, time-consuming methods, and allows the definition of objective quality criteria of sperm. Many authors have addressed possible utilities of the CASA system, like studying seasonal variations, xenobiotics effect, sperm quality, comparing differing activation conditions, selection of broodstock, improvement of sperm cryopreservation and storage techniques, etc. (Kime et al., 1996, 2001; Ravinder et al., 1997; Kime \& Nash, 1999). On the other hand, the system shows some limitations, the most important being the estimation of percentage of motility, a parameter frequently used for assessing sperm quality. The results obtained for this variable have low reproducibility, and an overestimation of percentage of motile sperm is usually observed. This problem seems to be linked to sample drift, when it is placed between slide and coverslip (even when it is very low) and may be less important when studying species with longer sperm motility duration. Stabilisation of drift is perhaps the most difficult technical problem to resolve since it is maximal at precisely the most interesting period of motility just after activation (Kime et al., 2001).

The estimation of the different motility parameters for seabass spermatozoa obtained in the present study is in agreement with those previously carried out in the same species (Dreanno, 1998; Fauvel et al., 1998, 1999; Dreanno et al., 1999b), where similar duration of sperm movement and attenuation of velocity were observed. Slight differences in the profiles of the variables measured can be accounted for the activating conditions, the time period in the reproductive season, reproductive status of the fishes, etc. In this work, besides, a complete characterization of a large set of sperm motility parameters is obtained. The duration of sperm motility in seabass is very short, around $50 \mathrm{sec}$. During the first $20-25 \mathrm{~s}$ sperm movement shows a steady behaviour, reaching the maximal values of velocity and linearity of the trajectories. During this time period, the probability of fertilization is the highest. In fact, Fauvel et al. (1998) found that fertilization ability decreases exponentially with time, no fertilization occurring if sperm had been active for more than ca. $30 \mathrm{sec}$.

Kime et al. (2001) indicated the lack of studies for marine species, regarding the effect of different variables, such as temperature or salinity, on sperm motility. No difference in the spermatozoa motility parameters measured was found when activating at different temperatures, but this result must be taken cautiously due to the fact that once the sample is placed on the Thoma cell it reaches room temperature very fast. In general, motility parameter values increase with temperature, while motility duration decreases (Alavi \& Cosson, 2005; pers. obs.). Several authors have reported an inverse relationship between sperm motility duration and temperature in salmonids (Billard \& Cosson, 1992; Vladic \& Jarvi, 1997; Van Look, Van Look \& Kime, unpublished observation cited in Kime et al., 2001). By contrast, wolffish Anarhichas lupus L. sperm activated at $18^{\circ} \mathrm{C}$ was motile for less than $1 \mathrm{~min}$, but could be reactivated by cooling and then it remained motile several days when activated at $4^{\circ}$ (Kime, unpublished observations cited in Kime et al., 2001).

Within the range studied, $\mathrm{pH}$ did not seem to affect sperm motility parameters significantly. This is in contrast with the results published for salmonids, where very low levels of motility were seen in sperm maintained at $\mathrm{pH}$ values at or below 7.5 prior to activation (Ingerman et al., 2002). Sansone et al. (2001) found, also in seabass, that spermatozoa were activated more efficiently in sea water at $\mathrm{pH} 8.2$ than at $\mathrm{pH} 7.5$. In the present study, the mean values of velocity and linearity are lower at $\mathrm{pH} 7.0$ and 8.5 in comparison with those obtained when activating at $\mathrm{pH} 7.5$ or 8.2 , although there is no statistically significant difference.

Among the three physicochemical variables assayed in the present study, osmolality appears to be the most effective in modifying sperm motility. Litvak and Trippel (1998) found in Atlantic cod Gadus morhua L. that the proportion of motile sperm decreased with decreasing salinity, and found variations of sperm swimming speeds at lower salinities. They indicated that recruitment levels could be influenced by annual variations in salinity of deep basin spawning areas, since low salinity can reduce fertilization rate. Haddy and Pankhurst (2000) also demonstrated an 
effect of salinity on motility, fertilisation and egg survival in black bream Acanthopagrus butcheri (Munro), though these authors did not test intermediate salinities and their study did not focus on sperm motility. Variations in sperm motility features with osmolality are not unexpected, since initiation of motility in most marine fish species is triggered by an hyperosmotic shock (Morisawa \& Suzuki, 1980; Cosson et al, 1999).

From our study, seabass spermatozoa appear to be sensitive to very low concentrations of $\mathrm{HgCl}_{2}$ and other mercury compounds (paracholomercury benzoate, data not shown), which is in agreement with the results obtained for other teleost species. Motility of catfish Clarias gariepinus (Burchell) spermatozoa can be decreased even at mercury concentrations as low as $1 \mathrm{ppb}$ (Rurangwa et al., 1998). In the present study, the minimum concentration which affected sperm motility was $0.1 \mathrm{ppm}$ but, as mentioned before, it is necessary to take into account the sperm dilution factor, especially considering the covalent nature of the binding of mercury ions. Kahn and Weis (1987) reported a significant decrease of VCL and fertilization success of mummichog Fundulus heteroclitus (L.) sperm after 2 min exposure to $0.01 \mathrm{ppm} \mathrm{HgCl}_{2}$, while exposure to $0.05 \mathrm{ppm} \mathrm{HgCl}_{2}$ caused a significant reduction in sperm motility. Van Look and Kime (2003) found a significant decrease of VCL in goldfish Carassius auratus auratus (L.)

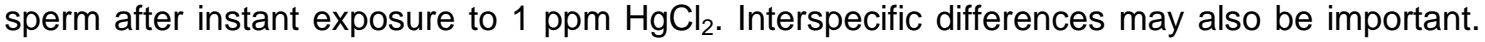
Huyskens and Van Look (unpublished data, from Kime et al., 2001) found, for example, cyprinids to be more tolerant to mercury contamination, observing a decrease in motility parameters at concentrations around $1 \mathrm{ppm}$. Species-specific differences in adenylate content and enzyme activities of teleost spermatozoa may determine a priori the vigour ant the duration of sperm movement and the sensitivity of the species sperm to toxicants (Rurangwa et al., 2002). As an example, Rurangwa et al. (1998) found in C. gariepinus a significant decrease in sperm motility at concentrations of $\mathrm{HgCl}_{2}$ as low as $0.001 \mathrm{ppm}$.

Several mechanisms of toxicity of $\mathrm{Hg}^{2+}$ on fish sperm motility have been proposed. Because of its known chemical reactivity towards sulphydryl residues, its binding to sulphydryl-dependent enzymes involved in sperm motility could cause breakage or twisting of the flagella, or could interfere with dynein- microtubule sliding assembly (Cosson et al., 1983). Impairment of the mitochondrial energy production has also been proposed (For review see Rurangwa et al., 1998; Van Look \& Kime, 2003).

Other likely target of $\mathrm{Hg}^{2+}$ could be the water channel protein, which appears to be specifically inhibited by very low concentrations of $\mathrm{HgCl}_{2}$ in other cell types (Kuwahara et al, 1997). Mercury sensitive water channel proteins have been recently identified in marine fish species (Santos et al, 2004). These transmembrane proteins could be directly responsible of the osmotic readjustment that takes place when spermatozoa are delivered into the surrounding medium (seawater for marine fishes) and the primary responsible for activation of motility (Alavi \& Cosson, in press). Inhibition of these water channels could also account for the deleterious effects of $\mathrm{HgCl}_{2}$ shown in figure 5. The osmotic reequilibration that would follow the osmotic shock (when sperm is exposed to seawater) cannot occur because water traffic across the membrane is prevented. This would lead to the shrinking and blebbing of the flagellar membrane already observed in other fish species (Cosson et al., 1999) .

Our own results argue in favour of the localisation of the target of $\mathrm{Hg}^{2+}$ in the plasma membrane: the demembranated flagellum appears much less sensitive to $\mathrm{Hg}^{2+}$ than the native spermatozoon. In addition, exposure to $\mathrm{Hg}^{2+}$ renders intact spermatozoa immotile, but they exhibit normal motility of their flagellar axonemes when demembranated.

The acute toxicity of copper and lead seems to be less important for seabass spermatozoa compared to other fish species. Kime et al. (1996) found in catfish that only concentrations of $1000 \mathrm{ppm}$ cadmium or $2000 \mathrm{ppm}$ zinc had any effect on motility when added to sperm at the final dilution step. In any case, it must be taken into account that, in natural conditions, sperm can be exposed to metal ions for much longer periods (sometimes during the whole life of the animal) and the development of appropriate incubation protocols that allow prolonged toxicity experiments will probably show higher sensitivity. It is also important to note that bioconcentration of pollutants is particularly important in hepatic and gonadal tissue where it may attain several orders of magnitude higher than in the surrounding water (Kime et al., 1996). Billard and Cosson (1992) identified some of the problems associated with the motility estimations made to date, as the type and ratio of diluents used. Many of the experiments do not report the dilution factors used and activation of sperm is carried out in normal sea water (subject to the variability). In the case of toxicity trials, as seen in the present set of experiments, it is of utmost importance to precisely define the conditions in which sperm is activated. As shown in figure $4 \mathrm{~b}$, there is a direct relationship between mercury lethal concentration and 
sperm concentration (expressed as the absorbance at $260 \mathrm{~nm}$ ). Nucleic acids have a peak of absorbance at this wavelength and measurement of absorbance has been found to be a good tool for assessing sperm concentration. An absorbance of 1.4 O.D. would correspond, following the formula $[\mathrm{sp}]=(0.806 \mathrm{OD}-0.032) \times 10^{8} \times 500$ (Fauvel et al., 1999), to $\sim 5 \times 10^{10}$ spermatozoa/ml. At a dilution $1 / 50$, this would mean $1 \times 10^{9} \mathrm{sp} / \mathrm{ml}$. As can be seen in figure $4 \mathrm{~b}$, the corresponding LC100 for 1.4 O.D is $\sim 4 \mathrm{ppm}$. This means, on average, $4 \times 10^{-9} \mu \mathrm{g}$ of $\mathrm{HgCl}_{2}$ per spermatozoon and, in terms of mercury molecules and number of binding sites, $\sim 9 \times 10^{6}$ mercury ions per spermatozoon $\left(1.5 \times 10^{-2} \mathrm{fM}\right)$.

Sperm swimming performance has been shown to be influenced by different environmental parameters and by different toxics. The correlation between sperm motility parameters and fertilization capability, which are clearly related, would mean the establishment of a fast technique for multiple purposes, like broodstock selection, development of toxicity tests, protocols for gamete storage... and, in summary, a useful tool for avoiding a good number of time-consuming fertilization experiments in which male gametes are tested.

\section{Acknowledgements}

The authors wish to thank Dr. Loizeau and Dr. Gómez Parra for their experienced suggestions, Erwann Fraboulet, for his helpful technical collaboration, and Dr. Antonio Medina, for his thorough revision of the manuscript. This study was partially funded by the European programme ASEFAF (HPRI-CT-2001-00146).

\section{References}

Alavi, S. M. H. \& Cosson, J. (2005). Sperm motility in fishes: (I) Effects of temperature and pH: a review. Cell Biology International 29, 101-110.

Alavi, S. M. H. \& Cosson, J. (in press). Sperm motility in fishes: (II) Effects of ions and osmotic pressure: a review. Cell Biology International.

Arukwe, A. (2001). Cellular and molecular responses to endocrine-modulators and the impact on fish reproduction. Marine Pollution Bulletin 42, 643-655.

Billard, R. \& Cosson, M. P. (1992). Some problems related to the assessment of sperm motility in freshwater fish. Journal of Experimental Zoology 261, 122-131.

Brooks, S., Tyler, C. R. \& Sumpter, J. P. (1997). Egg quality in fish: what make a good egg ?. Reviews in Fish Biology and Fisheries 7, 387-416.

Christ, S. A., Toth, G. P., McCarthy, H. W., Torsella, J. A. \& Smith, M. K. (1996). Monthly variation in sperm motility in common carp assessed using computer-assisted sperm analysis (CASA). Journal of Fish Biology 48, 1210-1222.

Ciereszko, A. \& Dabrowski, K. (2000). In vitro effect of gossypol acetate on yellow perch (Perca flavescens) spermatozoa. Aquatic Toxicology 49, 181-187.

Cosson, J. (2004). The ionic and osmotic factors controlling motility of fish spermatozoa. Aquaculture International 12, 69-85.

Cosson, J., Billard, R., Cibert, C., Dreanno, C., Linhart, O. \& Suquet, M. (1997). Movements of fish sperm flagella studied by high speed videomicroscopy coupled to computer assisted image analysis. Polish Archiv of Hydrobiology 44, 103-113.

Cosson, J., Dreanno, C., Billard, R., Suquet, M. \& Cibert, C. (1999). Regulation of axonemal wave parameters of fish spermatozoa by ionic factors. In The Male Gamete: from Basic Knowledge to Clinical Applications (Gagnon, C., ed.), pp.161-186. Vienna: Cache River Press. 
Cosson, M. P., Cosson, J., André, F. \& Billard, R. (1995). cAMP/AMP relationship in the activation of trout sperm motility: Their interaction in membrane-deprived models and in live spermatozoa. Cell Motility and the Cytoskeleton 31, 159-176.

Dreanno, C. (1998). Régulation de la mobilité des espermatozoids de turbot (Psetta maxima) et de bar (Dicentrarchus labrax): Etude du metabolisme énergetique, du contrôle ionique, de la morphologie, et du povoir fécondant. PhD Thesis. Rennes: University of Rennes.

Dreanno, C., Cosson, J., Suquet, M., Seguin, F., Dorange, G. \& Billard, R. (1999a). Nucleotides content, oxidative phosphorilation, morphology and fertilizing capacity of turbot (Psetta maxima) spermatozoa during the motility period. Molecular Reproduction and Development 53, 230-243.

Dreanno, C., Suquet, M., Fauvel, C., Le Coz, J.R., Dorange, G., Quemener, L. \& Billard, R. (1999b). Effect of the aging process on the quality of seabass (Dicentrarchus labrax) semen. Journal of Applied Ichthyology 6, 176-180.

Fauvel, C., Savoye, O., Dreanno, C., Cosson, J. \& Suquet, M. (1999). Characteristics of sperm of captive seabass in relation to its fertilization potential. Journal of Fish Biology 54, 356-369.

Fauvel, C., Suquet, M., Dreanno, C., Zonno, V. \& Menu, B. (1998). Cryopreservation of seabass (Dicentrarchus labrax) spermatozoa in experimental and production simulating conditions. Aquatic Living Resources 11, 387-394.

Haddy, J. A. \& Pankhurst, N. W. (2000). The effects of salinity on reproductive development, plasma steroid levels, fertilisation and egg survival in black bream Acanthopagrus butcheri. Aquaculture 188, 115-131.

Ingermann, R. L., Bencic, D. C. \& Gloud, J. G. (2002). Low seminal plasma buffering capacity corresponds to high $\mathrm{pH}$ sensitivity of sperm motility in salmonids. Fish Physiology and Biochemistry 24, 299-307.

Khan, A. T. \& Weis, J. S. (1987a). Effects of methylmercury on sperm and egg viability of two populations of killifish (Fundulus heteroclitus). Archives of Environmental Contamination and Toxicology 16, 499-505.

Khan, A. T. \& Weis, J. S. (1987b). Toxic effects of mercuric chloride on sperm and egg viability of two populations of mummichog, Fundulus heteroclitus. Environmental Pollution 48, 263-273.

Khan, A. T. \& Weis, J. S. (1987c). Effect of mercuric chloride on eggs and juvenile viability in two populations of killifish. Marine Pollution Bulletin 18, 504-505.

Kime, D. E., Ebrahimi, M., Nysten, K., Roelants, I., Rurangwa, E., Moore, H. D. M. \& Ollevier, F. (1996). Use of computer assisted sperm analysis (CASA) for monitoring the effects of pollution on sperm quality of fish; application to the effects of heavy metals. Aquatic Toxicology 36, 223237.

Kime, D. E. \& Nash, J. P (1999). Gamete viability as an indicator of reproductive endocrine disruption in fish. The Science of the Total Environment 233, 123-129.

Kime, D. E., Van Look, K. J. W., McAllister, B. G., Huyskens, G., Rurangwa, E. \& Ollevier, F. (2001). Computer assisted sperm analysis (CASA) as a tool for monitoring sperm quality in fish. Comparative Biochemistry and Physiology C 130, 425-433.

Kuwahara, M., Gu, Y., Ishibashi, K., Marumo, F. \& Sasaki, S. (1997). Mercury-sensitive residues and pore site in AQP3 water channel. Biochemistry 36, 13973-13978.

Lahnsteiner, F. (2000). Semen cryopreservation in the Salmonidae and in the Norhern pike. Aquaculture Research 31, 245-258. 
Lahnsteiner, F., Berger, B., Weismann, T. \& Patzner, R. A. (1998). Determination of semen quality of the rainbow trout, Oncorhynchus mykiss, by sperm motility, seminal plasma parameters and spermatozoal metabolism. Aquaculture 163, 163-181.

Litvak, M. K. \& Trippel, E. A. (1998). Sperm motility patterns of Atlantic cod (Gadus morhua) in relation to salinity: Effects of ovarian fluid and egg presence. Canadian Journal of Fisheries and Aquatic Science 55, 1871-1877.

Morisawa, M. \& Suzuki, K. (1980). Osmolality and potassium ion: their roles in initiation of sperm motility. Science 210, 1145-1147.

Ohta, H. \& Shinriki, Y. (1998). Changes in osmotic pressure that trigger the initiation of sperm motility in the river sculpin Cottus hangiongensis. Fish Physiology qnd Biochemistry 18, 29-35.

Ravinder, K., Nasaruddin, K., Majumdar, K. C. \& Shivaji, S. (1997). Computerized analysis of motility, motility patterns and motility parameters of spermatozoa of carp following short-term storage of semen. Journal of Fish Biology 50, 1309-1328.

Rurangwa, E., Biegniewska, A., Slominska, E., Skorkowski, E. F. \& Ollevier, F. (2002). Effect of tributyltin on adenylate content and enzyme activities of teleost sperm: a biochemical approach to study the mechanisms of toxicant reduced spermatozoa motility. Comparative Biochemistry and Physiology C 131, 335-344.

Rurangwa, E., Roelants, I., Huyskens, G., Ebrahimi, M., Kime, D. E. \& Ollevier, F. (1998). The minimum effective spermatozoa:egg ratio for artificial insemination and the effects of mercury on sperm motility and fertilization ability in Clarias gariepinus. Journal of Fish Biology 53, 402-413.

Rurangwa, E., Volckaert, F. A. M., Huyskens, G., Kime, D. E. \& Ollevier, F. (2001). A concerted strategy for the quality control of refrigerated and cryopreserved semen using computerassisted sperm analysis (CASA), viable staining and standardised fertilisation: application to preservation of sperm of African catfish (Clarias gariepinus) . Theriogenology 5, 751-769.

Santos, C. R., Estêvão, M. D., Fuentes, J., Cardoso, J. C., Fabra, M., Passos, A. L., Detmers, F. J., Deen, P. M., Cerdà, J. \& Power, D. M. (2004). Isolation of a novel aquaglyceroporin from a marine teleost (Sparus auratus): function and tissue distribution. Journal of Experimental Biology 207, 1217-1227.

Van Look, K.J.W. (2001). The development of sperm motility and morphology techniques for the assessment of the effects of heavy metals on fish reproduction. PhD Thesis. Sheffield: University of Sheffield.

Van Look, K. J. W. \& Kime, D. E. (2003). Automated sperm morphology analysis in fishes: the effect of mercury on goldfish sperm. Journal of Fish Biology 63, 1020-1033.

Vladic, T. \& Jaervi, T. (1997). Sperm motility and fertilization time span in Atlantic salmon and brown trout. The effect of water temperature. Journal of Fish Biology 50, 1088-1093.

Wagner, E., Arndt, R. \& Hilton, B. (2002). Physiological stress responses, egg survival and sperm motility for rainbow trout broodstock anesthetized with clove oil, tricaine methasulfonate or carbon dioxide. Aquaculture 211, 353-366.

Zar, J. H. (1996). Biostatistyical analysis. Upper Saddle River, NJ: Prentice-Hall. 


\section{Tables}

Table I.- Variation of several motility parameters with osmolality (mean $\pm \mathrm{sd}$ ). Values bearing different superscripts are significantly $(p<0.05)$ different from each other.

\begin{tabular}{|c|c|c|c|c|}
\hline \multirow{2}{*}{ Parameter } & \multicolumn{4}{|c|}{ Osmolality (mOsm/kg) } \\
\hline & $\begin{array}{l}580 \\
(n=7) \\
\end{array}$ & $\begin{array}{l}870 \\
(n=7)\end{array}$ & $\begin{array}{l}1165 \\
(n=8) \\
\end{array}$ & $\begin{array}{l}1320 \\
(n=8) \\
\end{array}$ \\
\hline $\operatorname{VSL}(\mu \mathrm{m} / \mathrm{s})$ & $61.45 \pm 14.05^{a}$ & $91.73 \pm 11.13^{\mathrm{b}}$ & $79.87 \pm 9.26^{b}$ & $64.65 \pm 5.52^{\mathrm{a}}$ \\
\hline $\operatorname{VCL}(\mu \mathrm{m} / \mathrm{s})$ & $165.91 \pm 10.50^{c}$ & $181.86 \pm 12.94^{\mathrm{b}, \mathrm{c}}$ & $156.68 \pm 10.53^{b}$ & $127.44 \pm 12.61^{\mathrm{a}}$ \\
\hline $\operatorname{VAP}(\mu \mathrm{m} / \mathrm{s})$ & $105.23 \pm 14.99^{a, b}$ & $138.84 \pm 12.25^{c}$ & $118.35 \pm 10.61^{b}$ & $97.44 \pm 8.96^{\mathrm{a}}$ \\
\hline STR (\%) & $54.36 \pm 5.02^{\mathrm{a}}$ & $63.69 \pm 4.03^{\mathrm{b}}$ & $65.36 \pm 3.82^{\mathrm{b}}$ & $65.63 \pm 4.82^{\mathrm{b}}$ \\
\hline $\operatorname{MAD}\left({ }^{\circ}\right)$ & $48.53 \pm 7.03^{c}$ & $33.0 \pm 3.13^{\mathrm{a}}$ & $38.5 \pm 5.41^{a, b}$ & $40.67 \pm 2.27^{b}$ \\
\hline LIN (\%) & $34.47 \pm 6.56^{a}$ & $48.25 \pm 5.10^{b}$ & $48.97 \pm 5.60^{b}$ & $50.05 \pm 3.50^{b}$ \\
\hline $\operatorname{BCF}\left(s^{-1}\right)$ & $7.87 \pm 0.86^{\mathrm{a}, \mathrm{b}}$ & $7.04 \pm 0.45^{\mathrm{a}}$ & $7.53 \pm 0.47^{\mathrm{a}}$ & $8.6 \pm 0.42^{b}$ \\
\hline $\mathrm{ALH}(\mu \mathrm{m})$ & $16.63 \pm 2.17^{\mathrm{c}}$ & $16.11 \pm 1.16^{\mathrm{c}}$ & $13.35 \pm 1.25^{\mathrm{b}}$ & $9.12 \pm 1.58^{\mathrm{a}}$ \\
\hline
\end{tabular}

\section{Figures}

Figure 1.- Evolution of several sperm motility variables (mean $\pm \mathrm{sd}$ ) provided by the CASA system after activation in AM $(n=8)$. 

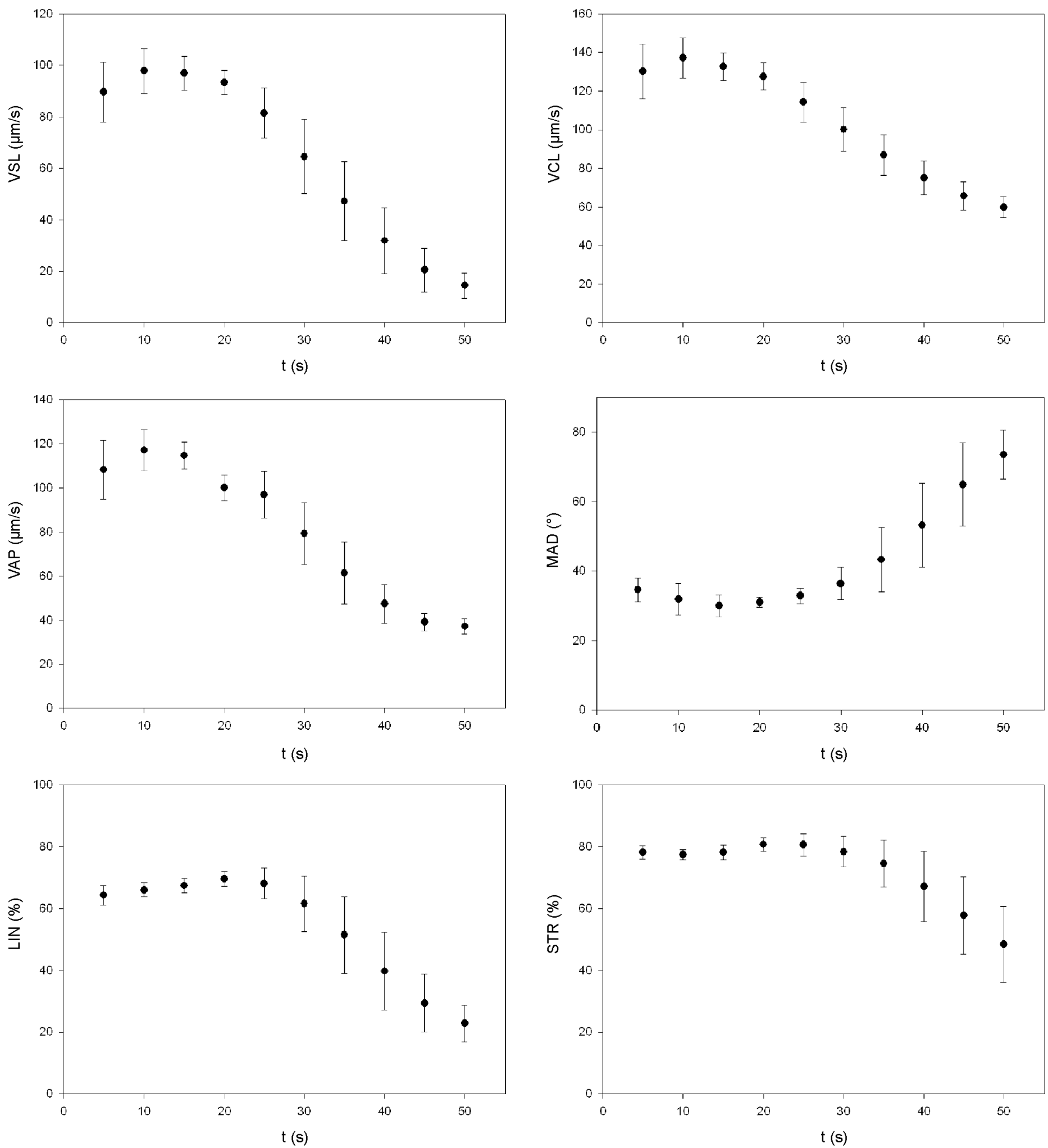
Figure 2.- Straight line velocity vs. metal concentration ( $\mathrm{ppm})$. Sperm was activated in BSAenriched AM containing different concentrations of the metal salts. Values are expressed as mean $\pm s d$, from 5 to 17 seconds after activation $(n=8)$. 
Figure 3.- Latereal head displacement and straight line velocity vs. metal concentration (ppm). Sperm was prediluted in BSA-free NAM containing different concentrations of $\mathrm{HgCl}_{2}$. Values are expressed as mean $\pm \mathrm{sd}$, from 5 to 17 seconds after activation in control AM. $(n=8)$. 

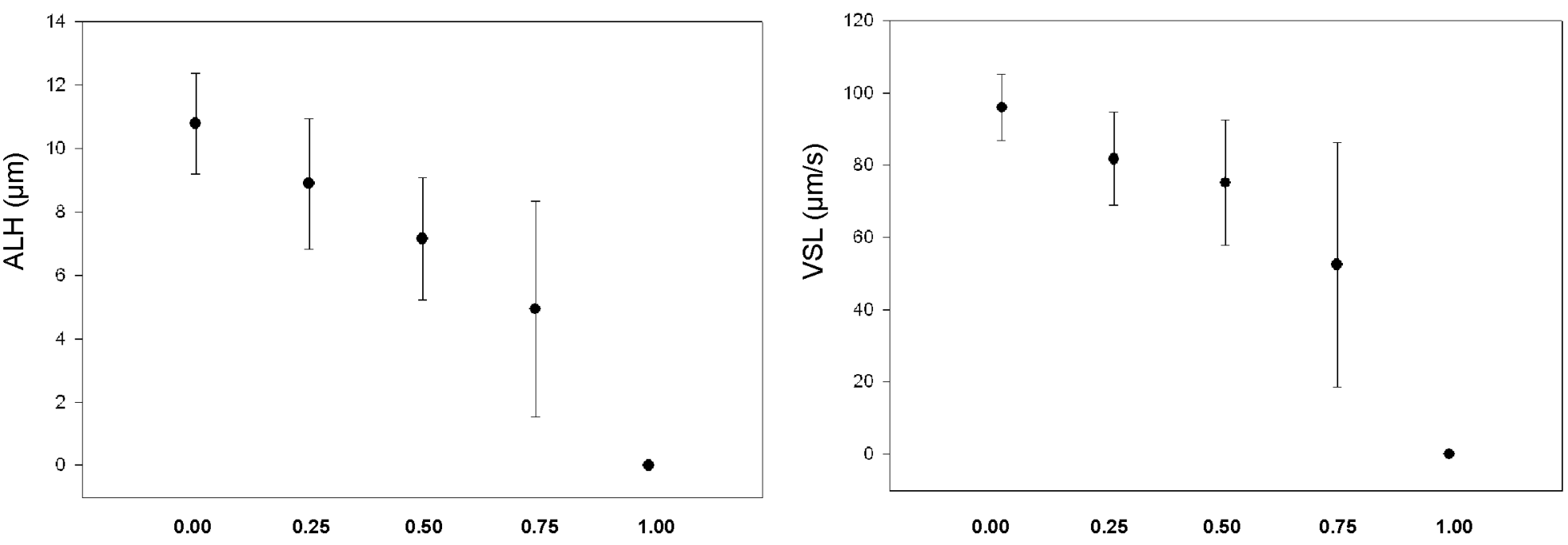

$\left[\mathrm{Hg}^{2+}\right]$

$\left[\mathrm{Hg}^{2+}\right]$ 
Figure 4.- LC100 vs. Sperm concentration. a.- LC100 vs. dilution factor. b.- LC100 (dilution factor: 1/50) vs. absorbance at $260 \mathrm{~nm}(\mathrm{n}=8)$. 

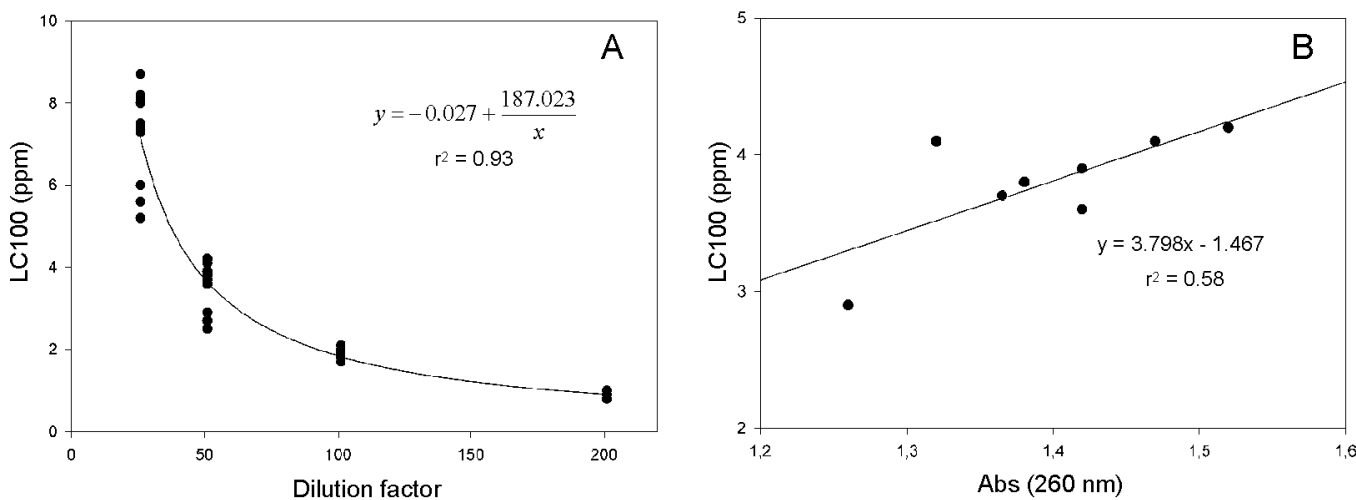
Figure 5.- Dark field microscopy images of native spermatozoa at the end of the motility period. a.- Sperm activated in control AM. b.- Sperm activated in $0.4 \mathrm{ppm} \mathrm{HgCl}_{2}$ AM. c.- Sperm activated in $4 \mathrm{ppm} \mathrm{HgCl}_{2} \mathrm{AM}$. 
